\title{
PSYCHOSEMANTIC TOOLS OF SELF-ASSESSING INDIVIDUAL REFLECTIVITY
}

\author{
Olena Savchenko \\ savchenko.elena.v@gmail.com \\ Vadym Hetman National Economic University of Kyiv, Ukraine
}

Received November 9, 2019; Revised December 2, 2019; Accepted December 26, 2019

\begin{abstract}
In this article, reflectivity is considered as an individual general ability to develop different attitudes to life events in order to reduce an external and internal uncertainty in situations. The objective of the research is to examine the self-assessment criteria for reflectivity with psychosemantic procedure. The author designs a modified version of the Ch. Osgood's (1957) Semantic Differential (SD) for examining the content and formal features of the self-assessment criteria of reflectivity. This study suggests two main processes of self-assessment of reflectivity, notably differentiation and integration. The results of factor analysis indicate that individuals with high reflectivity level are aligned with low differentiation of the semantic space and monolithic nature of self-assessment criteria. The coherence and consistency of self-assessment criteria reduce the individuals' level of inner uncertainty, transform external problems to familiar tasks and increase an efficient decision-making. A high level of differentiation is related to individual readiness to make a correct decision in the situation of multiple choice. High differentiation increases the individual adjustment and prevents from poor effects of high reflectivity. Consequently, a high level of reflectivity is associated with a low level of differentiation of self-assessment criteria.
\end{abstract}

Keywords: reflectivity, integration, differentiation, semantic space, psychosemantic tools.

\section{Савченко Олена. Психосемантичні засоби дослідження рефлексивної активності.}

Анотація. У статті рефлексивність розглядається як загальна здатність особистості ставати у різні позиції щодо подій власної життєдіяльності задля зниження ступеня зовнішньої та внутрішньої невизначеності. Мета дослідження - випрацювання оцінних критеріїв рефлективності на основі методів психосемантики. Автор розробила процедуру часткового семантичного диференціала, придатного для оцінки змісту і формальних рис рефлективності. Застосування факторного аналізу дало змогу виокремити лише дві узагальнені вторинні характеристики формальних ознак: рівень інтегрованості та диференціації. Виявлено, що високий рівень рефлексивності пов'язаний 3 низькою артикульованістю семантичного простору, з вираженою монолітністю оцінних критеріїв. Узгодженість та несуперечливість оцінних критеріїв допомагає суб'єктам знижувати рівень внутрішньої невизначеності, зводити зовнішні проблеми до типових задач. Висока артикульованість семантичного простору корелює з готовністю особи до перевірки висунутих припущень у ситуації множинного вибору, з домінуванням установки на правильність прийняття рішення. У результаті, встановлено, що високий рівень рефлексивності пов'язаний із низьким рівнем диференціації критеріїв оцінювання рефлексивної активності.

Ключові слова: рефлексивність, інтеграчія, диференціація, семантичний простір, психосемантичні засоби.

\footnotetext{
(C) Savchenko, Olena, 2019. This is an Open Access article distributed under the terms and conditions of the Creative Commons Attribution 4.0 International Licence (http://creativecommons.org/ licenses/by/4.0).

East European Journal of Psycholinguistics, 6(2), 98-106. https://doi.org/10.5281/zenodo.3637765
} 


\section{Introduction}

The reflectivity is a form of individual mental activity, which arises in situations of external or internal uncertainty. Evidence consistently suggests that external uncertainty is aligned with such features of the modern world as complexity, unpredictability, and instability (Halpern, 2011). Therefore, SPODworld (steady, predictable, ordinary, definite) has been replaced by VUCA-world (volatility, uncertainty, complexity, ambiguity). These changes predict a lot of challenges to individual, notably prompt adjustment to impermanent conditions, mobilization of necessary resources, maintenance of well-being and high performance, enhancing their activity at limited resource settings. These externally determined tasks stimulate the process of internal problem solving. Data from several studies suggest that that the person faces the following tasks, in particular chooses an efficient behavior strategy in a current situation, evaluates the importance and prioritizes own activity, predicts possible consequences, and adjusts personal attitude towards the situation (Gawronski \& Bodenhausen, 2006).

In our previous research, the selection, decision-making and solution of reflective tasks were considered as a way to reduce internal and external uncertainty and to cope with it with designed meta-plan. The setting and solution of reflective tasks contribute to the solution of external problems more successfully (Savchenko, 2016 a).

Several lines of evidence suggest that individual is reluctant to use reflective resources in familiar situations and applies automatizes behavioral and cultural patterns instead (Halpern, 2011). However, the stereotyped scheme might not be effective in unfamiliar situations with a high level of uncertainty. Non-standard situations force an individual to apply new suitable scheme for interpretation and decision-making in the new conditions. Schütz as cited in Chepeleva (2009) argued that an individual applies reflectivity in new circumstances, which confront with the everyday knowledge. Leontyev (2010) systematized the main characteristics of uncertain situations, notably these situations are always difficult, critical, stressful, and extreme. Moreover, they are atypical for an individual, generate a certain disruption in life, and are perceived as a threat to person`s integrity and well-being (Leontyev, 2010).

The internal resources reduce individual uncertainty in situations with high external ambiguity and stimulate the development of reflectivity as an individual general ability to mobilize their psychological resources and organize their selfanalysis process for capturing the solution of an external problem. Recent evidence suggests that reflection is a derived meta-process aimed at interpretation of external world events. As Lieberman and colleagues (2002) point out one system (C-system) analyzes the work of another system (X-system). "The C-system is a serial system that uses symbolic logic to produce the conscious thoughts that we experience as "reflections on" the stream of consciousness" (Lieberman, Gaunt, Gilbert, \& Trope, 2002, p. 219). Together, these studies indicate that reflectivity is an individual cognitive general ability to develop understanding and interpretation of different life events. 
Evidence consistently suggests that differentiation, integration, abstractness, cognitive complexity are the main characteristics of cognitive structures (Chuprikova, 1997). According to Chuprikova, the level of the system organization is "determined by the number of heterogeneous elements in the system (the degree of variety), the number of different levels (the degree of hierarchy), the number and variety of relations between elements and levels" (Chuprikova, 1997, p. 18). Therefore, the increase of differentiation and hierarchical order has a strong positive impact on system development. It is in line with the recent findings, which indicate an association between the developed conceptual system and processes of differentiation and integration (Harvey, Hunt, \& Schroeder, 1961; Pohilko \& Fedotova, 1984; Petrenko, 2010). Furthermore, if reflectivity is a complex conceptual system, processes of differentiation and integration have a great impact on its development.

There is a strong correlation between personal growth and development of conceptual system (Harvey et al., 1961). It is linked with strengthening the relationships between the components of system; the expansion of mental space by manipulating different features and functions of objects; the modification of cognitive processes resulting in changes of understanding and interpretation of different events; 4) the development of openness and dynamics of the system.

The development of conceptual system is aligned with concrete-abstract thinking and the relevant cognitive style. Individuals with the concrete thinking, and therefore, less developed conceptual system, demonstrate a tendency for black-andwhite thinking; dependence on status and authority; and intolerance of uncertainty. On the contrary, people with the developed conceptual system and abstract thinking are flexible, and change their behavior according to the requirements of situation. In addition, they often demonstrate creativity.

Our previous research suggests that level of individual reflectivity has a strong impact on students' academic performance (Savchenko, 2016b).

It is important to understand what mental mechanisms contribute to development of reflectivity and efficient decision-making in different situations. Despite the importance of reflectivity, there remains a paucity of evidence on selfassessment assessment criteria of reflectivity. Since reflectivity is aligned with cognitive and meta-cognitive processes, the present study applies methodology of psychosemantic. The aim of the research is to examine the self-assessment criteria for reflectivity with psychosemantic procedure.

\section{Methods}

The present study explores reflectivity as a conceptual system and the selfassessment criteria as its structure formed by experience. Researchers distinguish the content and formal characteristics of cognitive structure. Content characteristics are aligned with the typology of phenomena, whereas formal characteristics represent the structure of system and its particular components. In our previous study, the main content characteristics of the self-assessment criteria of reflectivity were defined, notably a goal for personal growth; readiness to solve problems; self- 
regulation; monitoring; planning; applying knowledge and experience; a positive attitude to efficient problem solving (Savchenko, 2015). 7) positive-negative attitude to problem solving.

The study applies the measure of Semantic Differential (SD) to assess reflectivity. The research uses a modified SD in which scales are appropriate for self-assessment of individual reflectivity. After transcribed self-reports during problem solving were obtained, the most frequent nouns, adjectives, and verbs were analyzed. The technique also selects the relevant antonyms to all words. The procedure results in developing 45 scales to assess individual mental activity in the situations of uncertainty. The scales represent various aspects of mental activity, particularly cognitive, evaluative, emotional and behavioral. In addition, the study captures the basic operations of self-assessment, notably representation, comparison, and generalization. The scales of cognitive aspects of reflectivity assess accuratefast thinking; self-accused-supportive thinking; rational - emotional thinking. The evaluative aspect of reflectivity includes productive - non-productive thinking, successful - unsuccessful thinking, self-assessing - not self-assessing thinking. The emotional aspect of reflectivity is aligned to such scales as stressed - relaxed; excited - quiet; cheerful - bored. The behavioral aspect is linked to such scales as focusing on my own results - focusing on others' results, comparison of the results and expectations - non-comparison of the results and expectations. The participants gave the responses while they were solving a problem. They assessed different aspects of the process, notably me while solving a familiar task; me solving a task in the situation with deficit of time; me while resolving a conflict; ideal me while solving a task; my resources at the present moment with 7 items anchored from $1=$ none of time to $7=$ all of the time. The study applies the Measure for Determining the Level of Reflectivity (Karpov \& Ponomareva, 2000) to assess the level of reflectivity in the participants. The study applies the principle component factor analysis with the rotation procedure Varymax, STATISTICA 10.0.

Participants. 450 individuals, 15-25 years old, were asked to assess the connotative meaning of the concepts with SD scales. The sample includes 77 high school students (17.1\%); 35 students of vocational schools (7.8\%); 228 university students $(50.7 \%)$; 76 working adults with higher education $(16.9 \%) ; 34$ working adults with secondary education $(7.6 \%)$. The study applies method of representative modeling for recruiting participants.

\section{Results and Discussion}

Table 1 summarizes the total amount of variance that can be explained by a given principle component factor analysis. The participants have a variety of selfassessment criteria of reflectivity $(\mathrm{M}=4.43 \pm .66)$. In addition, more than $0.44 \%$ of participants have only two self-assessment criteria, the majority of participants $(52.22 \%)$ have five or more self-assessment criteria, $38.89 \%$ of participants use four criteria for self-assessment, and $8.44 \%$ of participants use three criteria. Therefore, the results consistently suggest that reflectivity as an individual conceptual system is highly differentiated. 
Table 1

Descriptive statistics of self-assessment criteria of reflectivity

\begin{tabular}{|c|c|c|c|c|}
\hline Indices & $\mathrm{M} \min$ & $M \max$ & M & SD \\
\hline $\begin{array}{l}\text { Number of independent significant } \\
\text { components }\end{array}$ & 2 & 5 & 4.43 & 0.66 \\
\hline $\begin{array}{l}\text { Percentage of variance explained by the } \\
\text { first component }\end{array}$ & 21.3 & 69.2 & 32.4 & 6.65 \\
\hline $\begin{array}{l}\text { Percentage variance explained by the } \\
\text { second component }\end{array}$ & 14.1 & 36.7 & 23.8 & 3.48 \\
\hline $\begin{array}{l}\text { Difference between the first and the second } \\
\text { components }\end{array}$ & .01 & 55.1 & 8.54 & 7.91 \\
\hline $\begin{array}{l}\text { Number of variables included in the first } \\
\text { component }\end{array}$ & 4 & 29 & 12.9 & 4.09 \\
\hline $\begin{array}{l}\text { Bannister's coefficient of the first } \\
\text { component }\end{array}$ & 443 & 2813 & 1377.7 & 309.9 \\
\hline $\begin{array}{l}\text { Bannister's coefficient of the last } \\
\text { component }\end{array}$ & 137 & 1005 & 463.8 & 149.8 \\
\hline $\begin{array}{l}\text { Difference between Bannister's } \\
\text { coefficient`s of the first and the last } \\
\text { components }\end{array}$ & 103 & 2473 & 913.9 & 385.9 \\
\hline Bannister's total coefficient & 1629 & 4500 & 4284.7 & 420.58 \\
\hline
\end{tabular}

Table 1 illustrates that the first component explains almost a one-third of total dispersion $(\mathrm{M}=32.4 \pm 6.65)$, and the second component $(\mathrm{M}=23.8 \pm 3.48)$ explains significantly less variance $(\mathrm{t}=22.0 ; .999)$. The results indicate that there is a significant difference between dispersions of the first $(\mathrm{D}=44.28)$ and second $(\mathrm{D}=12.13)$ components $(\mathrm{F}=3.65 ; .999)$. Thus, evidence consistently suggests that only one significant component expresses individual self-assessment criteria of reflectivity in the participants. $5.56 \%$ of participants have the first component combined with more than 20 self-assessment criteria, which is an indicator of reflectivity as a low differentiated system. The first component of most participants $(66.89 \%)$ combines from 11 to 20 of self-assessment criteria of reflectivity. $27.54 \%$ of participants have high differentiated assessment criteria. In this case, the first component combines 10 self-assessment criteria.

There is a negative correlation between the number of components in principle component analysis and the level of reflectivity $(\mathrm{r}=-0.29 ; .99)$, the situational reflectivity ( $\mathrm{r}=-0.29 ; \alpha \geq 0,99)$, retrospective reflectivity ( $\mathrm{r}=-.29 ; .99)$, and prospective reflectivity $(\mathrm{r}=-.24 ; .95)$. There is a positive correlation between the level of reflectivity as a complex personal trait and variance explained by the first component $(\mathrm{r}=.21 ; .95)$, number of variables included in the first component $(\mathrm{r}=.26$; $.95)$, Bannister's coefficient of the first component $(\mathrm{r}=.31 ; .99)$ and Bannister's total coefficient $(\mathrm{r}=.33 ; .99)$.

One possible explanation of a negative correlation between the number of components in principle component analysis and the level of reflectivity is linked 
with constructive and destructive effects of reflectivity. Applying a lot of selfassessment criteria have a poor impact on efficient decision-making, since individual focusing on personal thoughts and experiences may ignore the important external factors of the situations. It is in line with the results of the recent research indicating the negative behavioral outcomes of reactivity, notably depressive states, neuroticism, ruminations, and deficit of cognitive resources (Nolen-Hoeksema, 2008; Leontyev \& Averina, 2011).

In order to prevent a negative outcome of reflectivity, it is necessary to control and regulate it. The control of mental activity is provided by metacognitive monitoring. According to Halpern's approach (2001), monitoring involves identifying priority tasks, assessing time and effort required to achieve a goal.

Table 2 illustrates the results of principle component factor analysis of selfassessment criteria of reflectivity.

Table 2

Summary of principle component factor analysis of self-assessment criteria of reflectivity

Indices

Factor loadings Component 1 Component 2

Number of independent significant components $-.50$ .67

Percentage variance explained by the first component

$.93-.07$

Percentage variance explained by the second component

Difference between the first and the second component variance

Number of variables included in the first component

Bannister's coefficient of the first component

Bannister's coefficient of the last component

.91

.95

$-.42$

.94

.23

54.2
.1

.04

.73

$-0.25$

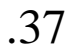

Bannister's total coefficient
Percentage variance explained by component

The results of the factor analysis confirm the assumption that there are at least two groups of indicators aligned with the self-assessment criteria of reflectivity, notably differentiation of mental activity and various aspects of activity, and integration of individual assessing criteria into more generalized factors. The first component expresses the tendency to integrate self-assessing criteria $(54.2 \%$ of the total variance). The tendency to integrate self-assessment criteria performs the important functions, notably decreasing the number of aspects applied for an efficient decision-making process; reducing uncertainty by the development of appropriate tools, skills, and problem solving algorithms. 
Laktionov (2010) suggests that integrating of self-assessment criteria is based on the individual ability to transfer meaning from one concept to the other concepts. This process is closely linked to an intermediate level of language competence, and is mostly not observed at a low level, when the individual demonstrates poor understanding of the criteria, and at a high level, when the individual demonstrates a high differentiation of the self-assessment evaluative criteria. The tendency to integrate the self-assessment criteria allows the individual to make deep interpretations and understanding the objective reality. A dual nature of selfassessment increases an individual adjustment, and develops the individual flexibility (Laktionov, 2010).

The data from table 3 illustrates the correlation between the first component expressing integration and the level of individual reflectivity. The most significant correlation is between the the level of individual reflectivity and Bannister's coefficient's of the first and the last components. The results indicate that reduction of analyzed alternatives in the situations with deficit of time contributes to the efficient problem solving.

Table 3

Correlation between the level of reflectivity and self-assessment criteria

\begin{tabular}{lccc}
\hline \multicolumn{1}{c}{ Indices } & \multicolumn{3}{c}{ The level of reflectivity } \\
\cline { 2 - 4 } & $\begin{array}{c}\text { situational } \\
\text { reflection }\end{array}$ & $\begin{array}{c}\text { retrospective } \\
\text { reflection }\end{array}$ & $\begin{array}{c}\text { perspective } \\
\text { reflection }\end{array}$ \\
\hline $\begin{array}{l}\text { Number of variables included in } \\
\text { the first component }\end{array}$ & .09 & $.21^{*}$ & $.24^{*}$ \\
$\begin{array}{l}\text { Bannister's coefficient of the first } \\
\text { component }\end{array}$ & $.22^{*}$ & $.25^{*}$ & $.26^{*}$ \\
$\begin{array}{l}\text { Difference between Bannister's } \\
\text { coefficient`s of the first and the last } \\
\text { component }\end{array}$ & $.26^{*}$ & $.28^{* *}$ & $.24^{*}$ \\
\hline
\end{tabular}

Note: $*$ - the correlation coefficient is significant at the level of .95; ** - the correlation coefficient is significant at the level of .99 .

\section{Conclusions}

This study has found the self-assessment criteria of reflectivity, presented by two mental processes, notably differentiation and integration. The component expressing integration is more significant, since it explains more than half of the individual differences and combines a greater number of self-assessment criteria. A general tendency towards low differentiation of the self-assessment criteria allows individuals to make efficient decisions in the situations of uncertainty. Taken together, high integration and low differentiation increase the individual adjustment and prevent from poor effects of high reflectivity. Consequently, a high level of reflectivity is associated with a low level of differentiation of self-assessment criteria. 


\section{Література \\ References}

Грановская Р. М. Психология веры. Санкт-Петербург: Питер, 2010.

Карпов А. В. Психология рефлексивных механизмов деятельности. Москва: Изд-во «Институт психологии РАН», 2004.

Карпов А. В., Пономарева В. В. Психология рефлексивных механизмов управления. М.: Издво ИП РАН, 2000.

Лактионов А.Н. Координаты индивидуального опыта. Харьков: Харьк. нац. ун-т им. В. Каразина, 2010.

Леонтьев Д.А. Психологические ресурсы преодоления стрессовых ситуаций: к уточнению базовых конструктов. Психология стресса и совладающего поведения в современном российском обществе: Материалы II Междун. научно-практич. конференции. Кострома: КГУ им. Н. А. Некрасова, 2010. № 2, 40-42.

Леонтьев Д.А., Аверина А.Ж. Феномен рефлексии в контексте проблемы саморегуляции. Психологические исследования. 2011. № 2(16). Режим доступа: http://psystudy.ru/index.php/num/2011n2-16/463-leontiev-averina16.html.

Петренко В. Ф. Основы психосемантики. Москва: Эксмо, 2010.

Похилько В. И., Федотова Е. О. Техника репертуарных решеток в экспериментальной психологии личности. Вопросы психологии, 1984, 3, 151-157.

Проблемы психологической герменевтики / Под ред. Н. В. Чепелевой. Киев : Изд-во Национального педагогического университета им. Н. П. Драгоманова, 2009.

Савченко О.В. Рефлексивна компетентність особистості. Херсон : ПП Вишемирський В. С., 2016

Савченко О. Структура семантичного простору, що відображає уявлення суб'єкта про власну рефлексивну активність // East European Journal of Psycholinguistics. 2015. Т. 2 (1), 114-123.

Чуприкова Н. И. Психология умственного развития: Принцип дифференциации. Москва : АО «Столетие», 1997.

Gawronski, B. \& Bodenhausen, G. (2006). Associative and propositional processes in evaluation: An integrative review of implicit and explicit attitude change. Psychological Bulletin, 132(5), 692-731.

Halpern, D. F. (2001). Assessing the Effectiveness of Critical Thinking Instruction. The Journal of General Education, 50(4), 270-286.

Harvey, O.J., Hunt, D. E., \& Schroder, H. M. (1961). Conceptual System and Personality Organization. New York: Wiley \& Sons.

Janzen, G. (2006). The Representational Theory of Phenomenal Character: A Phenomenological Critique. Phenomenology and the Cognitive Sciences, 5, 321-339 [in English].

Kriegel, U. (2003). Consciousness as Intransitive Self-Consciousness: Two views. Canadian Journal of Philosophy, 33, 103-132.

Lieberman, M. D., Gaunt, R., Gilbert, D. T., \& Trope, Y. (2002). Reflexion and reflection: A social cognitive neuroscience approach to attributional inference. In Advances in experimental social psychology (Vol. 34, pp. 199-249). Academic Press.

Nolen-Hoeksema, S., Wisco, B. E., \& Lyubomirsky, S. (2008). Rethinking rumination. Perspectives on Psychological Science, 3(5), 400-424.

Peters, F. (2013). Theories of consciousness as reflexivity. The Philosophical Forum, 44, 341-372.

Savchenko O. (2016b) The formation level of the components of the reflective experience as a factor of the students` educational success. Psychological Prospects, 28, 269-282. 


\section{References (translated and transliterated)}

Granovskaya, R. M. (2010). Psihologiya Very [Psychology of Faith]. S.-Petersburg: Piter.

Karpov, A. V. (2004). Psihologiya Refleksivnyh Mehanizmov Deyatelnosti [Psychology of Reflective Activity Mechanisms]. Moscow: Institute of Psychology of the Russian Academy of Sciences.

Karpov, A. V., Ponomareva, V. V. (2000). Psihologiya Refleksivnyh Mehanizmov Upravleniya [Psychology of Reflective Management Mechanisms]. Moscow: Institute of Psychology of the Russian Academy of Sciences.

Laktionov, A.N. (2010). Koordinaty Individualnogo Opyta [Coordinates of Individual Experience]. Kharkiv: Karazin National University of Kharkiv.

Leontyev, D. A. (2010). Psihologicheskie resursyi preodoleniya stressovyih situatsiy: k utochneniyu bazovyih konstruktov [Psychological resources of stressful situations overcoming: to clarify the basic constructs]. Psychology of Stress and Coping Behavior in Modern Russian Society. Book of Abstracts of the $2^{\text {nd }}$ International Scientific and Applied Conference, 2. Kostroma: Nekrasov Kostroma State University. (40-42).

Leontyev, D. A., Averina, A. Zh. (2011). Fenomen refleksii v kontekste problemyi samoregulyatsii [The phenomenon of reflection in the context of the problem of selfregulation]. Psihologicheskie Issledovaniya, 2(16). Retrieved from http://psystudy.ru/index.php/num/2011n2-16/463-leontiev-averina16.html.

Petrenko, V. F. (2010). Osnovyi Psihosemantiki [Fundamentals of Psychosemantics]. Moscow: Eksmo.

Pohilko, V. I., Fedotova, E. O. (1984). Tehnika repertuarnyih reshetok v eksperimentalnoy psihologii lichnosti [Repertory grid technique in experimental psychology of personality.]. Voprosy Psihologii, 3, 151-157.

Chepeleva, N. V. (Ed.). (2009). Problemy Psihologicheskoy Germenevtiki [Issues of Psychological Hermeneutics]. Kyiv: Drahomanov National Pedagogical University.

Savchenko, O.V. (2016a). Refleksyvna Kompetentnist Osobystosti [Personality`s Reflective Competence]. Kherson: Vyshemyrskyi.

Savchenko, O. (2015). Struktura semantychnoho prostoru, shcho vidobrazhaie uiavlennia subyekta pro vlasnu refleksyvnu aktyvnist [The Semantic space structure of the subject's sonception of his own mental activity]. East European Journal of Psycholinguistics, 2(1), 114-123.

Chuprikova, N. I. (1997). Psihologiya Umstvennogo Razvitiya: Printsip Differentsiatsii [Psychology of Mental Development: The Principle of Differentiation.]. Moscow: Stoletiye.

Gawronski, B. \& Bodenhausen, G.V. (2006). Associative and propositional processes in evaluation: An integrative review of implicit and explicit attitude change. Psychological Bulletin, 132(5), 692-731.

Halpern, D. F. (2001). Assessing the effectiveness of critical thinking instruction. The Journal of General Education, 50(4), 270-286.

Harvey, O.J., Hunt, D. E., \& Schroder, H. M. (1961). Conceptual System and Personality Organization. New York: Wiley \& Sons.

Janzen, G. (2006). The Representational Theory of Phenomenal Character: A Phenomenological Critique. Phenomenology and the Cognitive Sciences, 5, 321-339.

Kriegel, U. (2003). Consciousness as Intransitive Self-Consciousness: Two views. Canadian Journal of Philosophy, 33, 103-132.

Lieberman, M. D., Gaunt, R., Gilbert, D. T., \& Trope, Y. (2002). Reflexion and reflection: A social cognitive neuroscience approach to attributional inference. In M. P. Zanna (Ed.), Advances in experimental social psychology, 34 (pp. 199-249). Academic Press.

Nolen-Hoeksema, S., Wisco, B. E., \& Lyubomirsky, S. (2008). Rethinking rumination. Perspectives on Psychological Science, 3(5), 400-424.

Peters, F. (2013). Theories of consciousness as reflexivity. The Philosophical Forum, 44, 341-372.

Savchenko O. (2016b) The formation level of the components of the reflective experience as a factor of the students`educational success. Psychological Prospects, 28, 269-282. 